\title{
底泥の再浮上現象の現地観測およびそのシミュレーション \\ FIELD OBSERVATION AND SIMULATION OF DEPOSITION AND RESUSPENSION OF COHESIVE SEDIMENT IN A SHALLOW LAKE
}

\author{
大坪国順*・村岡浩 爾** \\ By Kuninori OTSUBO and Kohj̈ MURAOKA
}

\begin{abstract}
The main purpose of this study is to present and discuss the results of field observation and numerical simulation of deposition and resuspension of cohesive bottom sediment in a shallow lake. Field data taken in Lake Kasumigaura, such as lake current, wind over the lake, water wave, and turbidity of the lake, are shown. Based on these results, we discuss how sediments were suspended in this lake. We show the model to estimate the bottom shear stress causing sediment resuspension and the equations expressing the behavior of resuspended sediment in current which are used in the above simulation. The calculated turbidity showed a good agreement with that obtained by the field observation.
\end{abstract}

Keywords : cohesive sediment, resuspension, field research, simulation

\section{1. 概 説}

本研究は, 霞ケ浦高浜入における底泥の再浮上に関す る現地観測およびシミュレーションについて述べたもの である. 現地観測は底泥の再浮上の実態を把握するうえ で不可欠であり, 数理モデルは, 底泥中の栄養塩類の水 系への回帰量を推定したり，富栄養化防止・抑制対策を 検討するうえでの有力な手段となる. Sheng and Lick ${ }^{11}$ はエリー湖を対象に，吹送流による底泥の再浮上とそれ に伴う濁度の時間変化を計算した．濁度の鈆直方向の変 化や底泥層中の含水比の鉛直変化は無視し, 風向と濁度 の水平分布特性の関係を検討した，底泥の沈降・再浮上 に関する数理モデルの構築には，4つのサブシステムの 解明もしくはモデル化が必要である．すなわち，I）底 泥の限界掃流力と飛び出し率，II）底泥層内の含水比の 鉛直方向分布特性， III）底泥の再浮上の原因となるせん 断応力特性, IV ) 再浮上した底泥粒子の湖内での挙動の 4 つである. 図一1には，4つのサブシステムとそれら を解明するための方法, 手段などが示されている. サブ

* 正会員 工博 国立公害研究所主任研究員 水質土垣環境部 （河 305 茨城県筑波郡谷田部町小野川 16-2)

** 正会員 工博 国立公害研究所部長 水質土壌㻴境部 (同上)
システム I ），II）についてはすでに一応の成果が得ら

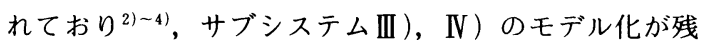
されている. 本論文では, 現地観測の結果, サブシステ ム III )，IV）のモデルの順に述べ, 最後に, 高浜入りで の濁度や底泥の浮上厚のシミュレーションの結果につい て実測結果との比較を交えながら検討する，III）につい ては, 波による底面せん断応力を実効掃流力なる量で評 価し, その時間変化を確率過程として取り扱った，VI)

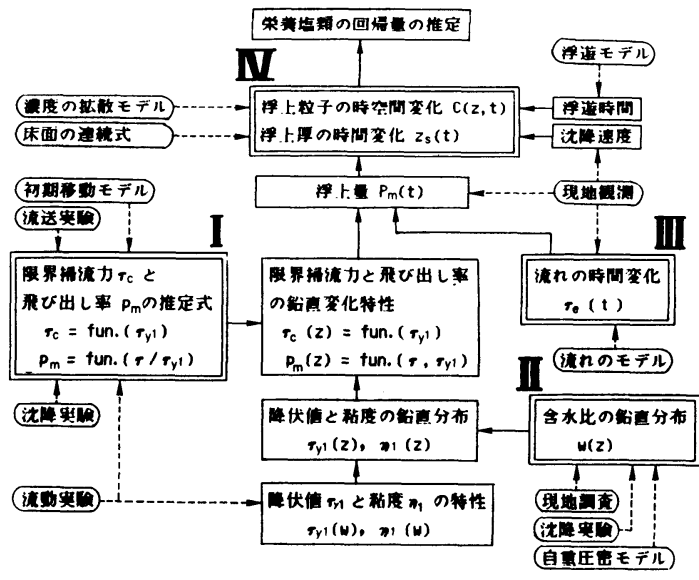

図一1 サブシステムの説明図 
については，鉛直方向のみの物質収支式を考えた。

\section{2. 現地観測結果 ${ }^{5)}$}

底泥の再浮上に関する現地観測は計測機器の防水など の保全の都合上, 高浜入湾奥部（図一2の st. 1) に係留 されている観測小屋で行った. 観測小屋は面積約 $25 \mathrm{~m}^{2}$ の観測用筏の上に設置されている (図一3参照). 小屋 の北東方向に隣接して面積約 $400 \mathrm{~m}^{2}$ の隔離水界が係留 されている. 観測地点の水深は $2.6 \mathrm{~m}$ で季節や天候な どにより $\pm 0.2 \mathrm{~m}$ 程度変化する. 観測項目は, 濁度, 風向・風速, 湖流(湖底面から約 $0.3 \mathrm{~m}$ 上方) および 波浪である．濁度は光透過式濁度計，風向・風速は微風 向風速計，湖流速および流向は電磁流速計，波高と波の 周期は容量式波高計（最大計測波高： $1 \mathrm{~m}$ ) により自動 計測され，カセット・テープもしくはペン・レコーダー に自動記録された．湖上観測のため，カー・バッテリー

（8 個並列）を計測機器の動力源とした. バッテリーの 交換頻度や各項目の計測間隔は, 計測機器の消費電力や 記録紙およびカセット・テープの容量（長さ）によって 決められた。

\section{（1） 風向・風速の特性}

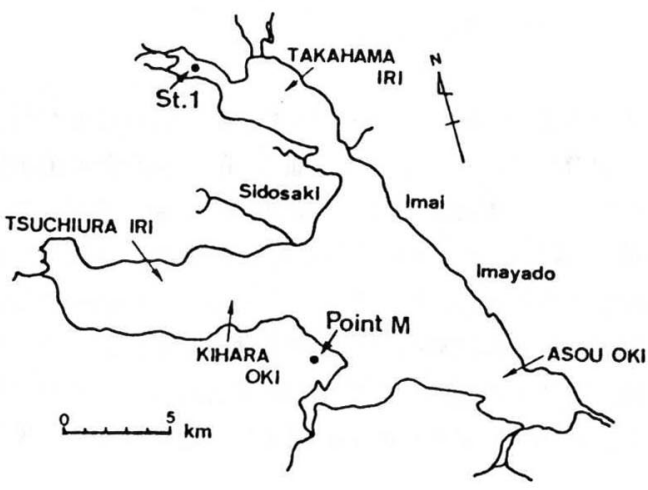

図一2 現地観測の地点

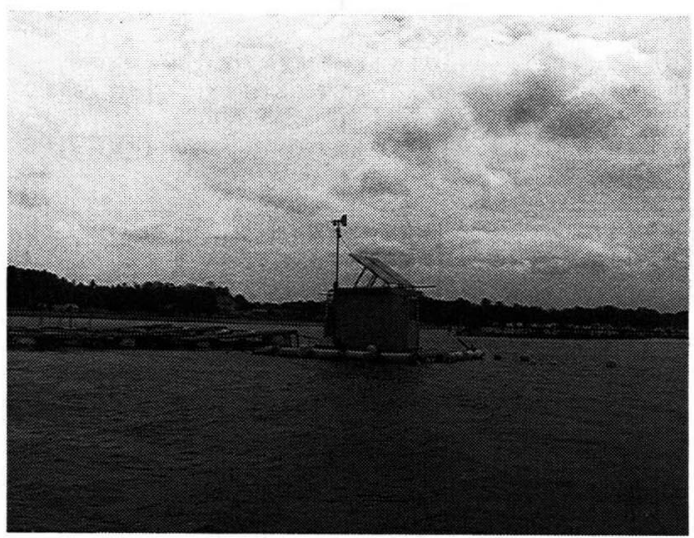

図一3湖上観測ステーション
風に関するデータは 30 秒おきに記録されるが，解析 には 30 分代表値を用いた. 霞ケ浦の周辺は平坦地形で あるので, 湖面上の風向・風速とも全域でほぼ一様と考 えられる. 実際, 最北部の高浜入り（図一2の st. 1) と 最南部に近い美浦村 (図一2の point $\mathrm{M}$ ) での風速の相 関係数は 0.92 であった. 観測期間中, 夏期には, E, $\mathrm{SE}$ および $\mathrm{S}$ の風向が卓越し, 秋・冬期には, $\mathrm{N}, \mathrm{NNE}$ および NNW の風向が卓越した. 夏期の風速変動のパ ワー・スペクトル結果には，1 日と半日に対応する波数 域に䫓著なピークが現われた。一方，秋期の結果には夏 期の場合ほど顕著なピークはないが，2.5 日程度に対応 する波数域に弱いピークが存在した. 夏期の最大風速は 台風時を除いて $6 \mathrm{~m} / \mathrm{s}$ 前後でさほど強くなかった．秋期 には, 風の強い日と弱い日が $2 \sim 3$ 日の周期で繰り返さ れた。強い風は終日続き, 日中の平均風速が $10 \mathrm{~m} / \mathrm{s}$ を 越す日もあった．冬期には，1月中旬過ぎから徐々に風 の強い日が多くなり，風速も大きくなった．

\section{（2）湖流の特性}

流速値は 2.5 秒ごとに計測されたデー夕を 5 分または 10 分ごとに平均して自動記録された．湖流速変動のパ ワー・スペクトルにも，夏期には，1 日相当の波数域に 弱いピークが, 秋期には, 2 3 日の波数域に弱いピー クが認められた．湖流速値は $50 \mathrm{~mm} / \mathrm{s}$ を越すことはま れで，平均は $10 \sim 20 \mathrm{~mm} / \mathrm{s}$ であった．風速と流速の相 関は，両者の 30 分平均値を用いても 0.05 とかなり低 かった。この結果は，村岡・福島による報告6)とほぼ一 致する.

（3）波の特性

記録紙やテープの長さの制限から，ペン・レコーダー では, 紙送り速度を $50 \mathrm{~mm} / \mathrm{min}$ と遅くして波高のみ押 え (20 分おきに 1 分間記録)，カセット・テープレコー ダー (1 時間おきに 1 分間記録) のデータからは波浪の 周期特性を求めた。

波高の整理が簡単にでき，また今回の記録法では他の 波高値と比しても信頼性は劣らないという理由で, 最大 波高 $H_{\max }(\mathrm{m})$ を選んで解析した. 最大波高と風速 $V_{w}$

$(\mathrm{m} / \mathrm{s}: 30$ 分代表値 $)$ との回帰分析の結果は次のようで ある.

$$
\begin{array}{ll}
H_{\max }=0.00275 V_{w}^{2}+0.021 & (\gamma=0.855) \cdots \cdots(1) \\
H_{\max }=0.047 V_{w}+0.134 & (\gamma=0.76) \cdots .(2)
\end{array}
$$

ここで $\gamma$ は相関係数である. 現地の不規則な波に対す る底面せん断応力の評価に際しては，有義波の概念が有 効と考えられるので，最大波高と風速との関係を有義波 とのそれに書き改める．波高分布が Rayleigh 分布と仮 定すれば, $N$ 波中の最大波高 $H_{\max }$ 之有義波高 $H_{1 / 3}(\mathrm{~m})$ の関係は近似的に式 (3) で与えられる77.

$$
H_{\max } / H_{1 / 3}=0.17 \sqrt{\log _{10} N} \text {. }
$$




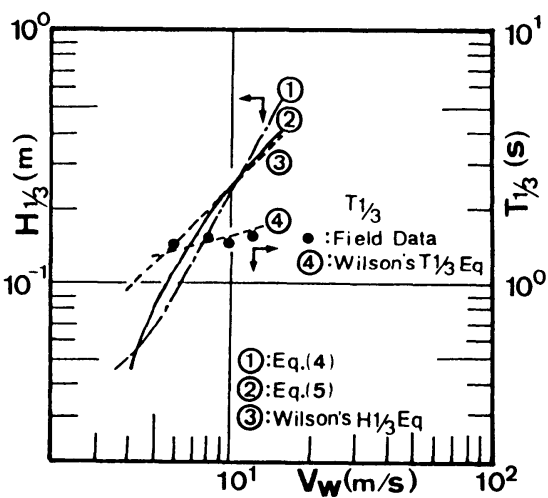

図一4 溲測地点での有義波の波高および周期

$N=30$ とおくと, 式（1）および（2）は次の 2 式と なる.

$$
\begin{aligned}
& H_{1 / 3}=0.0021 V_{w}^{2}+0.016 \\
& H_{1 / 3}=0.035 V_{w}-0.10 \cdots
\end{aligned}
$$

図一4中の曲線(1)および(2)は，それぞれ式（4）および

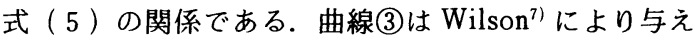
られた有義波高の推定式

$$
H_{1 / 3}=0.0024(F / g)^{1 / 2} V_{w}
$$

において，吹送距離 $F$ を $1 \mathrm{~km}$ とした場合である.

zero-up cross 法により求めた平均周期 $T_{m}$ は $H_{\max } も$ しくは $V_{w}$ と正の相関が認められた。図一4 中の○印は $H_{\max }$ と $T_{m}$ の実測データによる関係を, 式 $(1)$ と $T_{1 / 3}=1.1 T_{m}$ なる経験式 ${ }^{8)}$ を用いて, 風速 $V_{w}$ と有義波 の周期 $T_{1 / 3}$ との関係に直して示したものである. 図中 の曲線(4)は Wilson の $T_{1 / 3}$ の推定式 ${ }^{7)}$

$$
T_{1 / 3}=0.1096 \pi(F / g)^{1 / 3} V_{w}^{1 / 3}
$$

で $F$ を $1 \mathrm{~km}$ とした結果である．吹送距離 $F$ に対する 風向の影響などの問題も残るが, 観測地点付近の $H_{1 / 3}$ および $T_{1 / 3}$ は, 一応, 図一4の曲線(3)および(4)で評価 できると考えられる。

\section{（4）濁度の特性}

濁度については, 1983 年 7 月 28 日から 10 月 23 日ま では連続計测を行った。連続計測の場合，夜間には濁度 計光源部へ走光性動物プランクトンが集積し，そのプラ ンクトンを求めて魚類も集まるため, 濁度計は異常に高 い值を示した.これらの影響を除外するために, 直径 1 〜2 $\mathrm{mm}$ の孔を多数あけた硬質ビニールでセンサー部を 被い,さらに生物が嫌う有鉛塗料を塗布した。これを塗 布しないと魚の影響は防げるが, 動物プランクトンの集 積は防げず, 濁度計の出力は風のやむ夜間に $100 \mathrm{mg} / \mathrm{l}$ を越し, 逆に風が吹く日中に $40 \mathrm{mg} / l$ 以下となる日変動 パターンを示した. 一方, 有鉛塗料を塗布した場合には, 動物プランクトンの集積と思われる出力値の上昇は 10 $\mathrm{mg} / l$ 程度に抑えられた. 風速が $7 \mathrm{~m} / \mathrm{s}$ 程度の場合, 底
泥の再浮上による濁度の上昇が $10 \mathrm{mg} / l$ 程度であったた め, 朝夕の濁度の上昇が動物プランクトンの集積による のか底泥の再浮上によるのかを判断する必要が生じた。 動物プランクトンによる濁度の変化は緩慢であり, 底泥 の再浮上によるそれは急激であったので,この特徴をも とに判断した．動物プランクトンの影響を極力抑えるた めに, 10 月 24 日からは夕イマー作動により，30 分ごと に 5 分間計測する方法に切り替えた.これにより動物プ ランクトンの影響と思われる濁度の上昇はほとんどなく なった。

湖沼では，動植物プランクトンや各種の懸濁態物質が 常時浮遊して一定の濃度を保っている．この濃度を基底 濃度 $C_{b}$ とよぶことにする．晴天が続き風のないときの 濁度の観測值はこの $C_{b}$ に対応している， $C_{b}$ の値は夏 場の $30 \sim 40 \mathrm{mg} / l$ を最高に, 秋には $20 \mathrm{mg} / l$ 前後となり, さらに冬には $10 \mathrm{mg} / l$ 前後にまで徐々に低下した．この 値はその後春から夏にかけて再び上昇するという年変動 パターンを示したが，これは動植物プランクトンの生長 に深く関係している． $C_{b}$ は水表面と底面近傍を除いて， ほぼ一様であった．濁度の観測值 $C_{o b}$ から $C_{b}$ を差し引 いた值 $C_{p}$ が底泥の再浮上による濁度の上昇分と考えら れる. $C_{\rho}$ の値は, $6 \sim 7 \mathrm{~m} / \mathrm{s}$ の風速では $10 \mathrm{mg} / l$ 程度で あるが， $V_{w}>12 \mathrm{~m} / \mathrm{s}$ では精度が保証される計測範囲 $(110 \mathrm{mg} / l$ 以下) を越すことがあった。風が収まると $C_{\rho}$ の值は $1 \sim 2$ 時間以内に $10 \mathrm{mg} / l$ 以下に下がった. ま た, 観測ステーションの $\mathrm{NE}$ 方向に隔離水界実験用筏 （底面近くまで届く水中フェンスが取り付けられてい る）が隣接しているため, $\mathrm{N} \sim \mathrm{NE}$ 方向の風に対しては 筏の消波効果のため波が立たず，強風が 1 日続いた場合 でも $C_{p}$ の值は $10 〜 20 \mathrm{mg} / l$ 程度しか上昇しなかった。 $C_{o b}$ の值は図一8に示したが，ここでは $C_{p}$ と $V_{w}$ につい ての回帰分析結果について述べる.

$$
\begin{array}{ll}
C_{p}=0.016 V_{w}-0.09 & (\gamma=0.53) \cdots \\
C_{p}=0.000936 V_{w}^{2}-0.03 & (\gamma=0.53) \cdots \\
C_{p}=0.000070 V_{w}^{3}-0.08 & (\gamma=0.52) \cdots
\end{array}
$$

ここで $\gamma$ は相関係数である. この場合, $V_{w}>5 \mathrm{~m} / \mathrm{s}$ の 風速を対象とし, $\mathrm{N} \sim \mathrm{NE}$ 方向の風速のデータは除外し た. どの場合も $C_{p}$ と $V_{w}$ との間に高い相関が認められ る. 前述した波浪と風速の関係を考え合わせると, 霞ヶ 浦高浜入での底泥の再浮上を引き起こす主要因は，風に より誘起された波浪と考えられる.

\section{3. 現地での底面せん断応力}

\section{（1）実効掃流力}

底泥の限界掃流力および飛び出し率の推定式を用い て, 現地を対象とした底泥の再浮上のシミュレーション を行うためには，現地での流れの状態を底面せん断応力 
として評価する必要がある．湖底の底泥を浮上させる掃 流力 $\tau$ をそれに貢献する原因から次のように大別する ことにする.

$$
\tau=\tau_{w}+\tau_{f}+\tau_{t}
$$

ここで $\tau_{w}$ は風波によって付加されるせん断応力， $\tau_{f}$ は 湖流底面せん断応力である. $\tau_{t}$ は乱れによる変動分で, 底泥の飛び出し率を推定する際に考慮済みである ${ }^{3)} . \tau_{w}$, $\tau_{s}, \tau_{t}$ はテンソル量であるが, ここでは同方向とし，そ の方向は限定しない， $\tau_{f}$ は湖流の変化に伴ったゆった りとした変動成分を有しているし， $\tau_{w}$ も風波の周波数 域程度の比較的ゆっくりした変動成分を有しているが, $\tau_{w} ， \tau_{f}$ の上に，一様一方向流れにみられるような高周 波変動が重なっており，それを $\tau_{t}$ と書いている．今回 のシミュレーションでは, 湖流速 $V_{f}=60 \mathrm{~mm} / \mathrm{s}$ なる最 大級の值に対して, 抵抗係数を 0.02 として求めた 0.01 $\mathrm{N} / \mathrm{m}^{2}$ の值を $\tau_{f}$ として与え, これが定常的に働くとして いる. 湖流の観測結果からもわかるように $\tau_{f}$ の值は微 弱であるため, 霞ケ浦での底泥の再浮上に関与する主要 なせん断応力は $\tau_{w}$ と考えられる． $\tau_{w}$ という交番性の底 面せん断応力を底泥の掃流力としてゼう評価するかが問 題となる.

現地での波浪は不規則で，その波浪による底面せん断 応力を決定論的に記述することは非常に難しいため, 確 率論的手法が広く用いられている9 。ここでも, 底泥の 初期移動に対して, 底面せん断応力の向きは問題なく大 きさのみが効くと考え, 絶対値の平均で定義される実効 掃流力 $\tau_{e}$ 量を定義し, その時間変動を確率過程として とらえることにした，すなわち， $\tau_{e}$ をその平均値が風 速 $V_{w}$ とともに変動するようなランダム変数と考え, $V_{w}$ についての条件付き確率分布形としては正規分布を 仮定した。

$\tau_{e}$ の平均值 $\bar{\tau}_{e}$ を風速の関数として与える方法につい ては文献 5）に詳しいが，ここに，その手順を要約する. まず, 現地観測結果を基に得られた式（6)および式（7) から，風速 $V_{w}$ に対応する有義波の波高 $H_{1 / 3}$ および周 期 $T_{1 / 3}$ を求める. 次に $H_{1 / 3}$ および $T_{1 / 3}$ に微小振幅波 理論を適用して湖底での水粒子速度の振幅 $\hat{u}_{\mathrm{b}}$ を求め, この値と層流境界層理論加導かれる式 (12) 加ら $\hat{\tau}_{w}$ を求める. 最後に, 式 (13) で示される平均化操作から $\tau_{e}$ の平均値を求めるというものである.

$$
\begin{aligned}
& \hat{\tau}_{w}=\rho \sqrt{\sigma_{w} \nu} \hat{u}_{b} \\
& \bar{\tau}_{e}=\left(2 / T_{1 / 3}\right) \int_{0}^{T_{1 / 3} / 2} \hat{\tau}_{w}\left|\sin \left(k x-\sigma_{w} t+\theta\right)\right| d t \\
& =(2 / \pi) \hat{\tau}_{w}
\end{aligned}
$$

ここで, $\hat{\tau}_{w}$ は底面せん断応力の振幅, $\rho$ は水の密度, $\nu$ は水の動粘性係数, $\sigma_{w}=2 \pi / T_{1 / 3}, \theta$ は水粒子速度と掃 流力の位相差である，底面の粗度を $50 \mu \mathrm{m}$ として, 水
粒子速度の振幅が与えられたときの掃流力の振幅を層流 境界層理論, 梶浦による方法 ${ }^{9}$, Jonnson による方法 ${ }^{9}$ ( 両 方法とも乱流境界層理論）で計算した結果，砂粒の場合 と異なり，粗度が小さいため $\hat{\tau}_{L} / \hat{\tau}_{T}=2.0 \sim 10.0$ と層流 解の方が大きくなった。ここで $\hat{\tau}_{L}$ は層流として評価し た值， $\hat{\tau}_{T}$ は粗面乱流として評価した値である．滑面乱 流としての評価も考えられるが, 確立された方法がなく， ここでは， $\hat{\tau}_{L}$ で実効掃流力の平均値 $\bar{\tau}_{e}$ を評価した。

\section{（2）飛び出し率に及ぼす実効掃流力の变動の影整}

現地においては, 風速の変動により実効掃流力の平均 值が時間的に変化するだけでなく，風速が一定でも波の 不規則性や底泥面の凹凸などのさまざまな原因により， 底泥面に作用するせん断応力は実効掃流力の平均値のま わりに変動していると考えられる.すなわち，現地での 実効掃流力の時系列 $\tau_{e}(t)$ は, その平均值が風速の変動 に呼応するランダム過程として取り扱うのが適当と考え られる.ここでは，風速条件付きでの実効掃流力の分布 を平均値 $\bar{\tau}_{e}$, 標準偏差 $\sigma_{t}$ の正規分布之仮定する. 3. (1) の手順で与えられるが平均値 $\bar{\tau}_{e}$ に対して， $\alpha_{t}=\sigma_{t} / \bar{\tau}_{e}$ で 定義される変動係数が, 底泥の飛び出し率 $p_{m *}\left(\bar{\tau}_{\text {e* }}\right)$ の 統計的性質に及ぼす影響を検討することにする．上記の 実効掃流力の分布の仮定より, 底泥の無次元飛び出し率 の平均值 $\bar{p}_{\boldsymbol{m} *}\left(\bar{\tau}_{e * *}\right)$ および標準偏差 $\sigma_{t}\left(\bar{\tau}_{\text {e** }}\right)$ は次のように 表わされる.

$$
\begin{aligned}
& \bar{p}_{m *}\left(\bar{\tau}_{e *}\right)=\int_{0}^{\infty} p_{m *}\left(\tau_{e *}\right) f\left(\tau_{e *}\right) d \tau_{e *} \\
& \sigma_{\rho}\left(\bar{\tau}_{e *}\right)=\left[\int_{0}^{\infty} p_{m_{*}}^{2}\left(\tau_{e *}\right) f\left(\tau_{e *}\right) d \tau_{e *}-\left\{\bar{p}_{m *}\left(\bar{\tau}_{e *}\right)\right\}^{2}\right]^{1 / 2} \\
& f\left(\bar{\tau}_{e *}\right)=\left\{1 /\left(\sqrt{2 \pi} \sigma_{t *}\right)\right\} \exp \left[-\left\{\left(\tau_{e *}-\bar{\tau}_{e *}\right) /\left(\sqrt{2} \sigma_{t *}\right)\right\}^{2}\right]
\end{aligned}
$$

ここで, $f\left(\bar{\tau}_{e *}\right)$ は無次元実効掃流力 $\bar{\tau}_{e *}$ の確率密度関 数であり, $\tau_{e *}=\tau_{e} / \tau_{c 2}, \bar{\tau}_{e *}=\bar{\tau}_{e} / \tau_{c 2}, \sigma_{t *}=\sigma_{t} / \tau_{c 2}$ である. また $\bar{\tau}_{e}$ および $\sigma_{t}$ はそれぞれ $\tau_{e}$ の分布の平均值と標準 偏差であり， $\tau_{c 2}$ は底泥の破壊限界值 ${ }^{2}$ である. 実効掃流 力の分布の変動係数 $\boldsymbol{\alpha}_{\mathrm{t}}$ は

$$
\alpha_{t}=\sigma_{t} / \bar{\tau}_{e}=\sigma_{t *} / \bar{\tau}_{e *}
$$

で定義されるので, 式（17）を式（16）に代入すれば

$$
\begin{aligned}
f\left(\bar{\tau}_{e *}\right)= & \left\{1 /\left(\sqrt{2 \pi} \alpha_{t} \bar{\tau}_{e *}\right)\right\} \\
& \cdot \exp \left[-\left\{\left(\tau_{e *}-\bar{\tau}_{e *}\right) /\left(\sqrt{2} \alpha_{t} \bar{\tau}_{e *}\right)\right\}^{2}\right]
\end{aligned}
$$

となる. いま, $y_{*}=\left(\tau_{e *}-\bar{\tau}_{e *}\right) / \sigma_{t *}=\left(\tau_{e *}-\bar{\tau}_{e *}\right) /\left(\alpha_{t} \bar{\tau}_{e *}\right)$ とすると, 式 (14)，(15) は次のようになる.

$$
\begin{aligned}
& \bar{p}_{m *}\left(\bar{\tau}_{e *}\right)=\int_{-1 / \alpha_{t}}^{\infty} p_{m *}\left(k_{*} \bar{\tau}_{e *}\right) \Phi\left(y_{*}\right) d y_{*} \\
& \sigma_{p}\left(\bar{\tau}_{e *}\right)=\left[\int_{-1 / \alpha_{t}}^{\infty} p_{m_{*}}^{2}\left(k_{*} \bar{\tau}_{e *}\right) \Phi\left(y_{*}\right) d y_{*}\right. \\
& -\left\{\left.\bar{p}_{m *}\left(\bar{\tau}_{e *}\right)\right|^{2}\right]^{1 / 2}
\end{aligned}
$$

ここで， $\Phi\left(y_{*}\right)$ および $k_{*}$ は次式で定義される. 


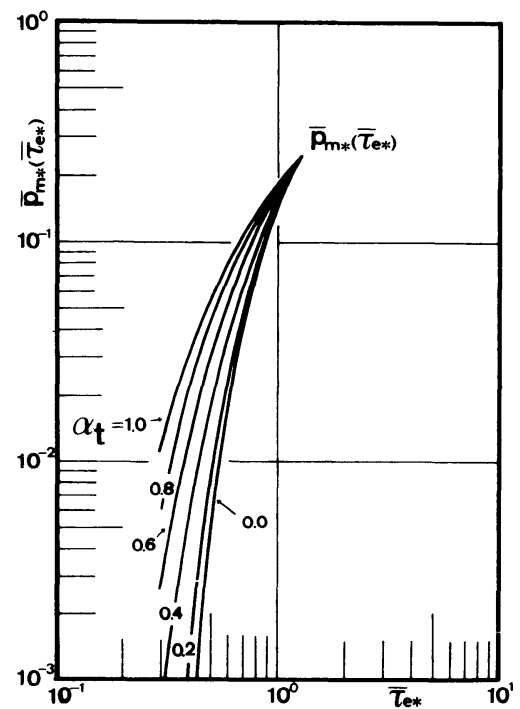

図一5 実効扭流力の变動を考虑した場合の底泥の無次元飛び出 し率 $\bar{p}_{m *}\left(\overline{\boldsymbol{\tau}}_{e *}\right)$

$\Phi\left(y_{*}\right)=(1 / \sqrt{2 \pi}) \exp \left(-y_{*}^{2} / 2\right), \quad k_{*}=y_{*} \alpha_{t}+1$

図一 5 は，実効掃流力 $\tau_{e}$ の変動を考慮に入れた場合の, 底泥の無次元飛び出し率の平均值 $\bar{p}_{m *}\left(\bar{\tau}_{e *}\right)$ と無次元実 効掃流力の平均值 $\bar{\tau}_{e *}$ の関係を, $\tau_{e}$ の変動係数 $\alpha_{t}$ をパ ラメーターにして整理したものである. $\bar{p}_{m *}\left(\bar{\tau}_{e *}\right)$ の值 は $\bar{\tau}_{e *}$ が 0.3 付近では $\alpha_{t}$ の值によって 2 オーダーほよ゙ 異なり， $\alpha_{t}$ が大きいほど大きくなる．しかし， $\bar{\tau}_{e *}$ が増 加するにつれて $\alpha_{t}$ による差が減少し, $\bar{\tau}_{e *}=1.2$ 付近で は $\alpha_{t}$ による違いは無視できる程度となる．図一5の結 果は, $\bar{\tau}_{\text {e* }}$ が小さくとも変動係数 $\alpha_{t}$ の值によっては, かなりの量の底泥が浮上し得ることを示晙している。

\section{4. 湖内での底泥の収支}

\section{（1）物質収支の基本式}

再浮上した底泥粒子の湖内での挙動について検討す る. 流水中で沈降・浮上を繰り返す物質の挙動を決定論 的に記述する一手段として，拡散方程式を用いて濃度分 布などの形で表現する方法がある。ここでも基本的には その方法を用いる. 底泥粒子の流水中での挙動は, 粒子 濃度 $C(x, y, z, t)$ に関する三次元拡散方程式を解くこ とにより求められるわけであるが，それをそのまま解く のは, 各方向の拡散係数の与え方の難しさなどのため, 煩雑で莫大な計算量のわりには大した精度が期待できな い.そのため, 通常は構成各項の断面平均値に対して物 質収支式が立てられる ${ }^{10)}$ 。観測点周辺は水深，波浪，湖 流条件がほぼ同じなので, 飛び出し率も水平方向に一様 と考えられる。 また，湖流速が小さいため，他の水域か
らの移流の影響も無視できると考えられる.そのため, 観測点周辺での浮上した底泥粒子の挙動は水平方向に一 様と仮定して, 次に示す鉛直方向のみの物質収支式を採 用した。

$$
h\left(\partial C_{m} / \partial t\right)=\left[E_{z}(\partial C / \partial z)\right]_{0}^{h}+\left[w_{0} C\right]_{0}^{h}
$$

ここで, $z$ 軸は鉛直上向き, $C$ は濃度, $C_{m}$ は断面平均 濃度, $w_{0}$ は粒子の沈降速度, $h$ は水深, $E_{z}$ は $z$ 方向の 拡散係数, $t$ は時間である. 境界条件は, 水表面では物 質が系外へ脱出しないという条件より

$\left[E_{z}(\partial C / \partial z)+w_{0} C\right]_{z=0}=0$

水底では単位時間単位面積当たり $P_{m}$ なる量の底泥粒子 が飛び出すという条件より

$\left[E_{z}(\partial C / \partial z)+w_{0} C\right]_{z=0}=-P_{m}+\left.w_{0} C\right|_{z=0}$

となる.この場合 $\left.E_{z}\right|_{z=0} \neq 0$ が前提となる.

$\left.C\right|_{z=0}=C_{0}$ と書き, 式 (23) および式 (24) を式 (22) に代入して整理すれば,

$$
\begin{aligned}
h\left(\partial C_{m} / \partial t\right) & =-\left.w_{0} C\right|_{z=0}+P_{m}+\left.w_{0} C\right|_{z=0}-w_{0} C_{0} \\
& =P_{m}-w_{0} C_{0} \ldots \ldots \ldots \ldots \ldots \ldots \ldots \ldots \ldots \ldots \ldots \ldots \ldots \ldots \ldots \ldots \ldots \ldots
\end{aligned}
$$

となる.ここで $C_{m}$ および $C_{0}$ について次の仮定をする. $C_{m}(t)$ および $C_{0}(t)$ の定義はそれぞれ

$$
C_{m}(t)=(1 / h) \int_{0}^{h} C(z, t) d z, \quad C_{0}(t)=C(0, t)
$$

であり，厳密には $C_{m}(t)$ および $C_{0}(t)$ を求めるために は, $C(z, t)$ の值が必要となるが,ここでは $C(z, t)$ の 鉛直分布形は常に相似で, 定常状態の方程式

$$
\partial\left\{E_{z}(\partial C / \partial z)\right\} / \partial z+w_{0}(\partial C / \partial z)=0 \cdots
$$

の解で近似できると仮定する.

\section{(2) 拡散 係数}

湖内の流れは, 波や鉛直循還流の存在により複雑と考 えられるが, 浮上した底泥の水中での拡散に関与するも のとしては, 湖流のみを考え, 簡単のためそれを, せん 断乱流とした，波浪は底面での巻き上げの主要因ではあ るが，微小振幅波として取り扱っているので，拡散には 関与しないと仮定した。 せん断乱れ場での拡散係数 $E_{z}$ は, 壁面や水表面では水粒子の運動が制限されるため小 さく, 主流部で大きい特性がある. そのため, 浮遊砂の 研究では， $E_{z}$ の分布として，対数分布則に基づく

$$
E_{z}=\beta u_{*} x z(1-z / h)
$$

がよく用いられてきた。この場合，式 (27) を満足する 鉛直濃度分布形 $C(z)$ は次の Rouse 型分布となる ${ }^{11)}$.

$$
C(z) / C_{a}=[\{(h-z) / z\} \cdot\{a /(h-a)\}]^{z *}, z_{*}=w_{0} /\left(\beta u_{*} x\right)
$$

ここで $\beta$ は底泥粒子の拡散に関する比例定数, $x$ はカル マン定数, $C_{a}$ は $z=a$ での濃度で規準面濃度とよばれ る. 式 (28) の $E_{z}(z)$ を用いた場合の問題点は $z=0$ に 規準面をとれないことである. すなわち，Rouse 型分 
布の場合, $a \rightarrow 0$ とすると, $C_{a} \rightarrow C_{0} \rightarrow \infty$ となり,式(25) の右辺は, $P_{m}$ が無限大でない限り常に負となり, 底泥 の浮上があっても湖内の濁度は全く上昇しないことにな る. そのため, 通常, $a / h=0.05$ に基準点が取られて いる. しかし， $a / h=0.05$ なる条件は水深 $h$ が大きく なると

$$
\left.E_{z}(\partial C / \partial z)\right|_{z=a}=-P_{m}
$$

が成立しない. そのため $C_{a}$ の值を何らかの形で与えて いる. しかし, 著者らは, 参考文献 3) において $P_{m}$ の 推定式を導いているので, 式 (25) のように $P_{m}$ を取り 組んだ形の物質収支式を用いたい。 そのためには， $z=$ 0 で $E_{z}=0$ 以外の拡散係数を与えたい。，そのような分布 として, 式 (28) の断面平均值 $E_{z}=\beta u_{*} x h / 6$ を用いる ことがよく行われてきた.この場合, 式 (27) を満足す る $C(z)$ は次のような指数分布となる.

$C(z) / C_{0}=\exp \left(-6 z_{*} z / h\right)$.

ここで, $C_{0}$ は $z=0$ での濃度であり, $\left.E_{z}\right|_{z=0} \neq 0$ である ために定義が可能となり, 式（25）の収支式が適用でき る. しかし, $E_{z}=\beta u_{*} x h / 6$ (=const. ) なる仮定は, 壁 面付近で問題となる.このように，上記 $2 つ の E_{z}$ の与 え方には互いに問題点を含んでいる. そこで, 乱流場 $(a$ $<z \leqq h)$ での, 物質の拡散係数 $E_{z}$ 之運動量の拡散係 数との間の仮定を全層 $(0 \leqq z \leqq h)$ まで抬張して,

$$
E_{z}=\beta \nu+\beta u_{*} x z(1-z / h)
$$

と仮定すれば，この分布形は $E_{z}$ の值が境界付近で小さ く主流部で大きいという特性を満足し，かつ規準面を $\boldsymbol{z}$ $=0$ で定義できる.ここで, $\nu$ は水の動粘性係数である. ただ， $E_{z}$ を式 (32) で与えた場合, 式 (27) を満足す る濃度分布形は解析的には表現できず少し不便である.

そこで, 主に解析の便宜のために, 拡散係数 $E_{z}$ の分布 形としては次のように式 (32) を近似する.

$$
\begin{array}{ll}
E_{z}=E_{z 1}=\beta \nu & 0 \leqq z \leqq a \cdots \cdot(33 \cdot \mathrm{a}) \\
E_{z}=E_{z u}=\beta u_{*} x z(1-z / h) & a \leqq z \leqq h \cdots \cdot(33 \cdot \mathrm{b})
\end{array}
$$

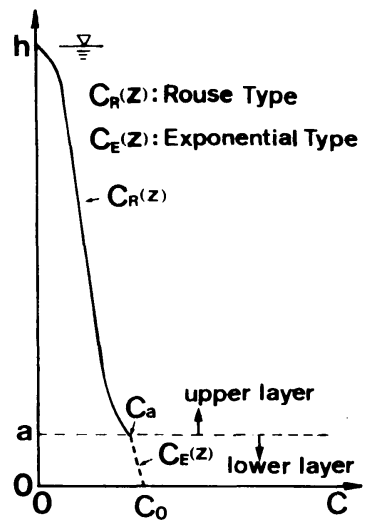

図一6 䝶度分布形モデルに関する説明図
式 (33) は, $z \rightarrow 0$ では $\beta \nu \gg \beta u_{*} x z(1-z / h)$ であり, $z$ が大きくなるにつれて $\beta \nu \ll \beta u_{*} x z(1-z / h)$ を考慮し たものである。これによれば, 濃度分布形 $C(z)$ は図一 6 のようになる.すなわち, $C(z)$ は $0 \leqq z \leqq a$ の下層部 では指数型濃度分布を， $a \leqq z \leqq h$ の上層部では Rouse 型濃度分布を考える.この濃度分布形は $z=a$ において $C(z)$ は連続であるが微分不可能となる．しかし， $C(z)$ に対する時間的相似性などの仮定を踏まえれば，この近 似は許容されると考えられる.

ここで $C_{m u}$ および $C_{m 1}$ をそれぞれ上層 $(a \leqq z \leqq h)$ および下層 $(0 \leqq z \leqq a)$ での断面平均濃度とすると, 式 (25) は次のように書き改められる.

$$
(h-a)\left(\partial C_{m u} / \partial t\right)+a\left(\partial C_{m 1} / \partial t\right)=P_{m}-w_{0} C_{0} \cdots
$$

上・下層の接続面 $a$ の位置は $E_{z u}(a)=E_{z 1}(a)$ 条件で決 めることにすれば， $a$ は次の関係式から求められる.

$$
\nu=u_{*} x a(1-a / h)
$$

$a$ が微小な場合， $1-a / h=1$ となるので， $a$ は結局

$$
a=\nu /\left(u_{*} x\right)
$$

で近似される. $x=0.4$ として, $a$ の值と粘性底層厚 $\delta_{1}\left(=5 \nu / u_{*}\right)$ との比を求めると $a / \delta_{1}=0.5$ となり，aの 位置は粘性底層内に存在することになる。

（3）シミュレーションに用いた物質収支式

濁度の計算值を観測結果と比較するためには，観測地 点（底泥面から $0.3 \mathrm{~m}$ 上方）での濁度 $C_{o b}(t)$ を求める 必要がある. そのために，まず式 $(34)$ を $z=a$ での濃 度 $C_{a}$ に関する式に書き改めることとする．濃度分布形 の仮定より,

$$
M_{a R}=(h-a) C_{m u}=\int_{a}^{h} C_{R} d z=\int_{0}^{h} C_{R} d z-\int_{0}^{a} C_{R} d z
$$

となる．ここで， $C_{R}$ は Rouse 型濃度分布である．よっ $\tau$

$$
\begin{aligned}
M_{a R}= & C_{a} h\left\{f_{a} /\left(1-f_{a}\right)\right\}^{z_{*}} \int_{0}^{h}\{(1-f) / f\}^{z_{*}} d f \\
& -C_{a} h\left\{f_{a} /\left(1-f_{a}\right)\right\}^{z_{*}} \int_{0}^{a}\{(1-f) / f\}^{z_{*}} d f
\end{aligned}
$$

となる.ここで, $z_{*}=w_{0} /\left(\beta u_{*} x\right), f=z / h$ および $f_{a}=$ $a / h$ である. 式 (38) の 2 つの積分項は, $0<z_{*}<1$ の 場合積分可能である ${ }^{12)} . u_{*}=3.2 \mathrm{~mm} / \mathrm{s}, \quad w_{0}=0.46$ $\mathrm{mm} / \mathrm{s}$ の条件を与えると $z_{*}=0.3$ であり， $M_{a R}$ は結局,

$$
\begin{aligned}
M_{a R}= & C_{a} h\left\{f_{a} /\left(1-f_{a}\right)\right\}^{z_{*}} \Gamma\left(1-z_{*}\right) \Gamma\left(1+z_{*}\right) \\
& -C_{a} h\left\{f_{a} /\left(1-f_{a}\right)\right\}^{z_{*}} F\left(1-z_{*},-z_{*}, 2-z_{*} ; f_{a}\right)
\end{aligned}
$$

となる.ここで $\Gamma(x)$ はガンマ関数, $F(a, b, c ; z)$ は 超幾何関数である.また $a C_{\boldsymbol{m}}$ は濃度分布形の仮定より,

$$
a C_{m 1}=\int_{0}^{a} C_{E} d z=\left\{C_{a} E_{z 1} /\left(k_{e} w_{0}\right)\right\}\left\{1-\exp \left(-w_{0} a / E_{z 1}\right)\right\}
$$


で表わされる.ここで， $C_{E}$ は指数型分布である. また， $k_{e}=C_{a} / C_{0}$ であり $\exp \left\{-w_{0} a /(\beta \nu)\right\}$ で与えられる. 式

（33）と式（39）および式（40）を式（34）に代入して 整理すれば,

$$
\begin{aligned}
& {\left[h\left\{f_{a} /\left(1-f_{a}\right)\right\}^{z_{*}} \Gamma\left(1-z_{*}\right) \Gamma\left(1+z_{*}\right)\left(\partial C_{a} / \partial t\right)\right.} \\
& -h\left\{f_{a} /\left(1-f_{a}\right)\right\}^{z_{*}} F\left(1-z_{*},-z_{*}, 2-z_{*} ; f_{a}\right) \\
& \left.+\left\{\beta \nu /\left(k_{e} w_{0}\right)\right\}\left[1-\exp \left\{-w_{0} a /(\beta \nu)\right\}\right]\right\} \\
& \cdot\left(\partial C_{a} / \partial t\right)=P_{m}-w_{0} C_{a} / k_{e}
\end{aligned}
$$

となり,これを解けば $z=a$ での濃度の時間変動 $C_{a}(t)$ が求められる. $z=h_{o b}$ での濃度の時間変動 $C_{o b}(t)$ は, $C_{a}(t)$ を式 $(29)$ に代入して, $z=h_{o b}$ とすることにより 求められる.

\section{5. 底泥首内の含水比の鉛直分布の影翼}

ここでは, 堆積している底泥の含水比の鈆直分布が底 泥の再浮上現象に及ぼす影響を, 底泥床高の時間的変化 を例にとって検討する. 簡単のため, 流れは時間的に変 化せず，浮上した粒子の流下距離は無限大とする．便宜 上, 無次元飛び出し率 $p_{m *}$ の推定式 ${ }^{3)}$ を次式で近似する.

$$
p_{m *}=A\left(\tau / \tau_{c 2}\right)^{\lambda} \quad\left(\text { for } \tau / \tau_{c 2}<1\right)
$$

ここで, $\tau$ は底面せん断応力, $A$ および $\lambda$ は比例定数で ある. 実験結果 ${ }^{2}$ をもとに, $\tau_{c 2}=\alpha \tau_{y 1}$ （ $\tau_{y 1}$ : 降伏値， $\alpha$ : 定数）と近似すると, 底泥床面での連続式は次式とな る.

$$
\begin{aligned}
d z_{s *} / d t_{*} & =A_{1}\left(d_{0} / z_{b 0}\right)\left(\eta_{1} / \eta_{0}\right)^{-1}\left(\tau / \alpha \tau_{0}\right) p_{m *} \\
& =A_{1} A\left(d_{0} / z_{b 0}\right)\left(\eta_{1} / \eta_{0}\right)^{-1}\left\{\tau /\left.\left(\alpha \tau_{0}\right)\right|^{\lambda+1}\left(\tau_{y 1} / \tau_{0}\right)^{-\lambda}\right.
\end{aligned}
$$

ここで, $z_{s *}=z_{s} / z_{b 0}, t_{*}=\left(\alpha \tau_{0} / \eta_{0}\right) t, z_{s}$ は底面低下量, $t$ は時刻, $A_{1}$ は粒子の形状係数, $d_{0}$ は飛び出し時の代 表的粒径, $z_{b 0}$ は基準底泥層深さ， $\eta_{1}$ は底泥の粘度， $\tau_{0}$ および $\eta_{0}$ はそれぞれ $z_{b}=z_{b 0}$ における $\tau_{y 1}$ および $\eta_{1}$ の 值である. $z_{b}$ 軸は鉛直下向きである. 含水比を濃度 $C$ で表現しその鈶直分布形 $C\left(z_{b}\right)=c_{1} z_{b}^{l}\left(c_{1}, l\right.$ : 定数 $)$ とし, さらに実験結果 ${ }^{2)} よ り$ 近似される $\tau_{y_{1}}=k_{1} C^{m}, \eta_{1}$ $=k_{2} C^{n}\left(k_{1}, k_{2}, m, n:\right.$ 実験定数 $)$ なる関係を用いて整 理すれば, $d z_{b} / d t$ は

$$
\begin{aligned}
& d z_{s *} / d t_{*}=A_{1} A\left(d_{0} / z_{b 0}\right)\left\{\tau /\left(\alpha \tau_{0}\right)\right\}^{\lambda+1} z_{s *}^{-l(\lambda m+n)} \\
& \left(\tau / \tau_{c 2}<1\right)
\end{aligned}
$$

と書き改められる. 実験や調査の結果から, $\lambda=5, l=$ $1 / 5, m=n=4$ となり, $\{l(\lambda m+n)+1\}=29 / 5$ を 6 と近 似すれば, $z_{s *}$ の時間変化は次式となる.

$$
z_{s *}=\left(6 A_{1} A d_{0} / z_{b 0}\right)^{1 / 6}\left\{\tau /\left(\alpha \tau_{0}\right)\right\} t^{1 / 6}
$$

$$
\left(\tau / \tau_{c 2}<1\right)
$$

$C\left(z_{b}\right)=$ const. の場合には, 底泥路床の低下量（すなわ ち, 底泥の浮上厚さ) $\Delta z_{s}$ が時間に比例して増加する のに比べて, $C\left(z_{b}\right)=c_{1} z_{b}^{1 / 5}$ のような濃度変化をしてい る場合には, $\Delta z_{s}$ は時間の $1 / 6$ 乗に比例し大幅に減少
する. また，同じ経過時刻での $\Delta z_{s}$ は, $C\left(z_{b}\right)=$ const. の場合には $\tau / \alpha \tau_{0}$ の 6 乗に比例するのに対し, $C\left(z_{b}\right)=$ $c_{1} z_{b}^{1 / 5}$ の場合には $\tau / \alpha \tau_{0}$ に比例することになり， $\tau$ の増 加に伴う $\Delta z_{s}$ の増加は $C\left(z_{b}\right)=$ const. の場合に比べて かなり小さくなることがわかる. 以上の考察で, 堆積し た底泥の含水比の鉛直変化が, 底泥の再浮上現象に大き な影響を及ぼすことが明らかとなった．現地の条件に よっては, 浮上量を推定する際, 含水比の鉛直方向変化 を考慮した解析が必要となると考えられる.

\section{6. 底泥の再浮上に関するシミュレーション}

これまでに得られた知見をもとに，霞ヶ浦高浜入湾奥 部を対象として底泥の再浮上現象のシミュレーションを 行った. 本節では, その手順および結果について述べる. シミュレーションにおいては, 風速の時間変動を入力と して与え, 深さ $0.3 \mathrm{~m}$ での濁度および底泥の浮上厚 $z_{s}$ (洗掘深) の時間変化を出力として得ようとするもので ある. まずシミュレーションの具体的な手順について説

\section{表一1 底泥属内での底泥の粘度と限界㧎流力の鉛冝分布}

\begin{tabular}{|c|c|c|c|c|}
\hline $\begin{array}{c}z_{6} \\
(\mathrm{~mm})\end{array}$ & $\begin{array}{c}\mathrm{C} \\
(\mathrm{kg} / 1)\end{array}$ & $\begin{array}{c}\mathrm{w} \\
(\mathrm{q})\end{array}$ & $\begin{array}{c}\mathrm{n}_{1} \\
(\mathrm{~Pa} . \mathrm{s})\end{array}$ & $\begin{array}{c}{ }^{\tau} \mathrm{C}^{2} \\
\left(\mathrm{~N} / \mathrm{m}^{2}\right)\end{array}$ \\
\hline $0.0-0.5$ & 0.124 & 760 & 0.05 & 0.07 \\
\hline $0.5-1.0$ & 0.137 & 690 & 0.08 & 0.11 \\
\hline $1.0-.2 .5$ & 0.151 & 620 & 0.12 & 0.15 \\
\hline $2.5-5.0$ & 0.158 & 590 & 0.17 & 0.21 \\
\hline $5.0-10.0$ & 0.172 & 540 & 0.23 & 0.26 \\
\hline $10.0-20.0$ & 0.183 & 500 & 0.28 & 0.32 \\
\hline
\end{tabular}

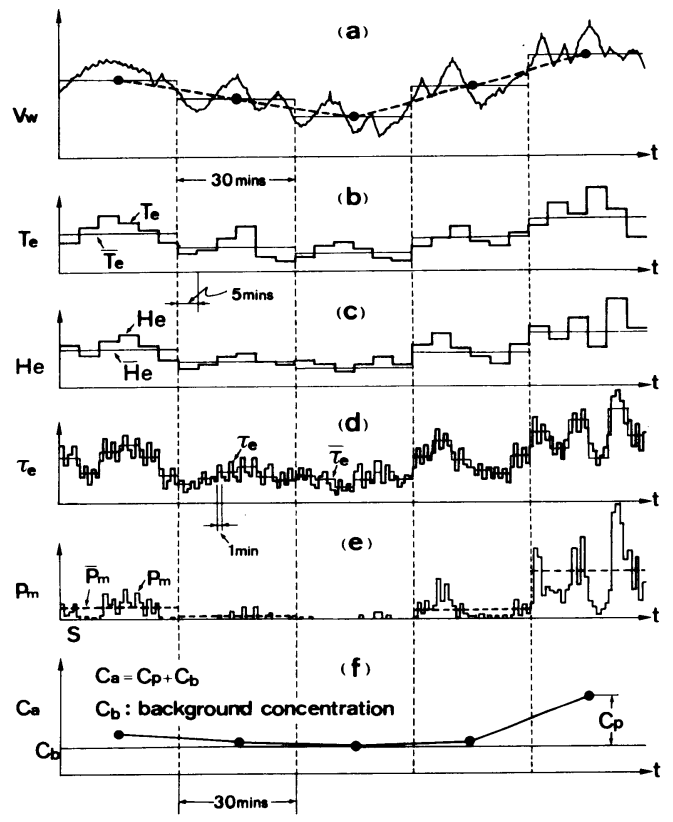

図一7実効掃流力の時系列を与える手順の説明図 
明し, 計算結果と現地観測結果との比較などを通してシ ミュレーションの妥当性について検討する．ここでは均 一でその性質に時間的変化のない固体粒子を想定した。 また，ここで取り扱う底泥の浮上現象は，せいぜい表層 $1 \mathrm{~cm}$ 前後の巻き上げで，底泥は降伏しておらず（すな わち，底泥層としては流動せず)，表層のより柔らかな 部分から間欠的に巻き上がるというものである.

\section{（1） シミュレーションの手順}

シミュレーションにあたって, 底泥層内の含水比の鈆 直分布を反映させて限界掃流力 $\tau_{c 2}$ や底泥の粘度 $\eta_{1} に つ$ いて，その鉛直方向変化を考慮に入れた．また底泥床面 に作用するせん断応力を, 平均値が風速によって決めら れる正規分布型確率変数として与えた。.濁度や浮上厚さ の時間変動は 30 分間隔で計算したが, 実効掃流力 $\tau_{e}$ の 値は 1 分ごとに与えた。具体的な手順は次のとおりであ る.

（1) 含水比の鈶直分布の実測データを参照して，底泥 層を表一1に示すように分割し，各層での含水比に対応 する $\eta_{1}\left(z_{b}\right)$ および $\tau_{c 2}\left(z_{b}\right)$ の值を与える ${ }^{2)}$.ここで $z_{b}$ 軸 は鉛直下向きである（表面で $z_{b}=0$ ).

(2) 実効掃流力は以下の手順で与える. 入力としての 風速は図一7(a) のように 30 分ごとに一定值で与える. 30 分間の平均值としての波高 $\bar{H}_{e}$ および周期 $\bar{T}_{e}$ は, そ れぞれ式（6）および式（7）から計算する. 30 分間 内の風速変動の影響と, 風速之有義波の関係に内在する ばらつきとを考慮して, 有義波の波高 $H_{e}$ と周期 $T_{e}$ を, $\bar{H}_{e}$ および $\bar{T}_{e}$ を平均値とし, 変動係数が $\alpha_{H}$ および $\alpha_{T}$ である正規分布型の確率変数として 5 分ごとに与える (図一7（b ），(c ）参照).

(3) 有義波 $H_{e}, T_{e}$ に対応する実効掃流力 $\bar{\tau}_{e}$ は 3. (1) に述べた手順で求める，さらに，実際の波浪は不規則波 であるので, その影響を $\bar{\tau}_{e}$ に加味して, $\tau_{e}(t)$ は 1 分ご とに確率変数 (平均値: $\bar{\tau}_{e}$, 変動係数： $\alpha_{t}$, 正規分布型) として与える (図一7 $(\mathrm{d})$ 参照).

(4) 与えられた $\tau_{e}(t)$ の值と表一 1 に示す $z_{b}=z_{s}$ での 限界掃流力 $\tau_{c 2}$ 之粘度 $\eta_{1}$ の值を, 底泥の飛び出し率の推 定式 ${ }^{3)}$ である式 (46) に代入して, 1 分間ごとの飛び出 し量 $P_{m}(t)$ を計算する. $z_{s}$ は浮上厚であるが, 時刻 $t$

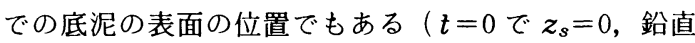
下向きが正).

$$
\begin{aligned}
p_{m *} & =\left(A_{2} / A_{3}\right)\left(\eta_{1} / \tau\right)\left\{P_{m} /\left(\rho_{0} d_{0}\right)\right\} \\
& =\left(a_{2} / a_{1}\right) p_{0}\left\{1+\delta_{0} \Phi\left(y_{0}\right) / p_{0}-\tau_{c 2} / \tau\right\} .
\end{aligned}
$$

ここで, $A_{2}, A_{3}=$ 粒子の形状係数で, それぞれ， $\pi / 4$, $\pi / 6 ; \rho_{0}, d_{0}=$ 飛び出す粒子の密度および粒径; $a_{1}=1$, $a_{2}=0.75 ; p_{0}=\tau>\tau_{c 2}$ なる確率; $\delta_{0}=\tau$ の変動係数 $(=$ $0.5) ; \Phi(y)=$ 誤差関数; $y=(\tau-\bar{\tau}) / \sigma_{1} ; \bar{\tau}=\tau$ の平均値; $\sigma_{1}=\tau$ の標準偏差である.
(5). $P_{\boldsymbol{m}}(t)$ の 30 分間平均値 $\bar{P}_{\boldsymbol{m}}$ を求めて, この $\bar{P}_{\boldsymbol{m}}$ の 値と物質収支式の式 (41) を用いて $z=a$ での濁度 $C_{a}$ の時間変動を 30 分ごとに計算する（図一7 (e ), ( f ) 参照).

(6) 観測点での濁度 $C_{o b}$ は $C_{a}$ の値と式 (29) を用い て計算する. 底泥の浮上厚 $z_{s}$ は, 水中に浮遊している 単位面積当たりの底泥粒子の全量 $M_{T}\left(C_{b}\right.$ の分は除く) を計算し, 次に示す関係式から逆算する.

$$
z_{s}=\left(M_{\tau} / \rho\right)(1+w / 100) \cdots
$$

この際, 沈降してきた底泥は, 一定の含水比 $w=590 \%$ で堆積するとした． $\rho$ は底泥粒子の真の密度である.

\section{（2）シミュレーション結果の考察}

想定した底泥粒子は, 粒径 $26 \mu \mathrm{m}$, 比重 2.28 で沈降 速度は $0.46 \mathrm{~mm} / \mathrm{s}$ である. 湖内での鉛直分布形を与え る $z_{*}$ の值は $\beta=1.2, x=0.4$ および $u_{*}=3.2 \mathrm{~mm} / \mathrm{s}$ と して 0.3 とした. 水深は $2.5 \mathrm{~m}$, 観測点の位置は底面か ら $0.3 \mathrm{~m}$ 上方である. また, 確率変数 $H_{e}, T_{e}$ および $\tau_{e}$ に対する変動係数の值は試行錯誤的に決められ，それぞ れ $\alpha_{H}=0.025, \alpha_{T}=0.025$ および $\alpha_{t}=0.5$ で一定とした. 図一8 は上記の条件で行った濁度 $\left(h_{0 b}=0.3 \mathrm{~m}\right)$ および 浮上厚の時間変動のシミュレーション結果である. 同図 には風向, 風速, 濁度の現地観測デー夕を併示した。（A） が 1983 年 11 月 6 日から 11 月 19 日，（B）が 1984 年 1 月 14 日から 1 月 28 日までの結果である. 濁度について 実測値と計算値を比較すると，風速が $10 \mathrm{~m} / \mathrm{s}$ を越すと 計算值は必ず $200 \mathrm{mg} / \mathrm{l}$ を越える高い值となるが, 実測 值は必ずしもそうはならない，この原因は風向にあると 考えられる. 風速が $10 \mathrm{~m} / \mathrm{s}$ を越えても濁度が 10２0 $\mathrm{mg} / \mathrm{l}$ 程度しか上昇していない実測データの場合, 風向 は $\mathrm{N} \sim \mathrm{NE}$ となっている. $\mathrm{N} \sim \mathrm{NE}$ の風向の風は，観測 ステーションの位置の関係で, 吹送距離が $200 \mathrm{~m}$ 程度 と短い。さらに観測ステーションの NE 方向に, 約 400 $\mathrm{m}^{2}$ の規模の実験施設がわずか数 $\mathrm{m}$ 離されて係留されて おり，これによる消波効果が大きい，以上の 2 つが， $\mathrm{N}$ ～NE 方向の風の速度が $10 \mathrm{~m} / \mathrm{s}$ を越えても, 高い濁度 が観察されなかった理由と考えられる.この考察を裏付 けるデータとして, $\mathrm{N} \sim \mathrm{NE}$ 方向以外の風が $10 \mathrm{~m} / \mathrm{s}$ を 越す場合には $110 \mathrm{mg} / l$ という高い濁度が観測されてい る.なお, 出力値としてはもっと高い値が記録されてい たが, $110 \mathrm{mg} / l$ 以上は計測精度が保証されていないの で，図一8の実測値は $110 \mathrm{mg} / l$ で切ってある. $\mathrm{N} \sim \mathrm{NE}$ 方向の風のデータを除いて，実測値亡計算値の相関係数 を求めたところ 0.67 とかなり高く, 今回のシミュレー ションは妥当なものと判断される.実測された濁度では, 風速が $8 \mathrm{~m} / \mathrm{s}$ を越すあたりから急激に上昇し始め, 風速 が $6 \mathrm{~m} / \mathrm{s}$ 以下になると 1 2 時間以内にもとの值に下降 する特徵がみられたが, シミュレーションでもその特徵 

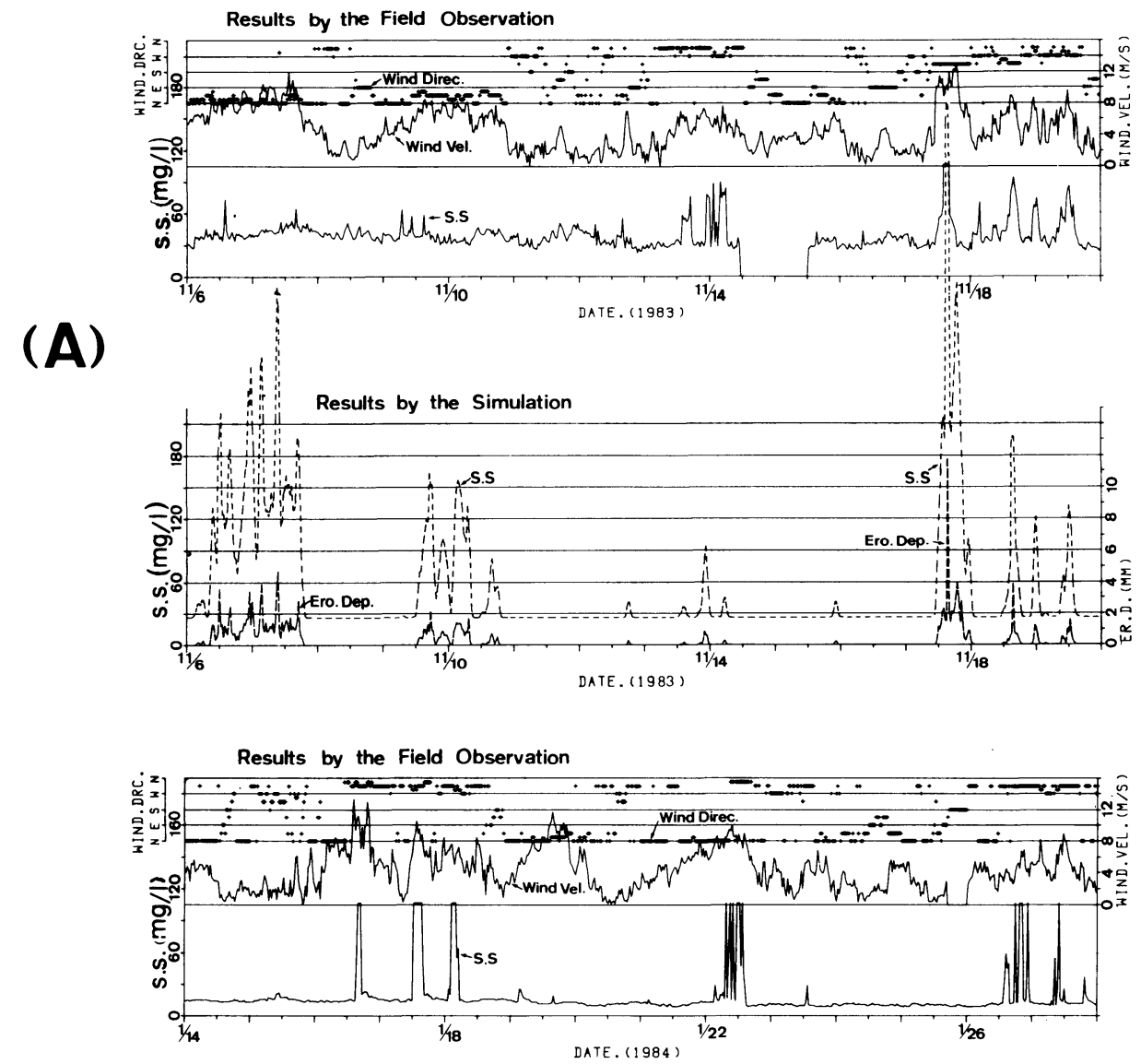

(B)

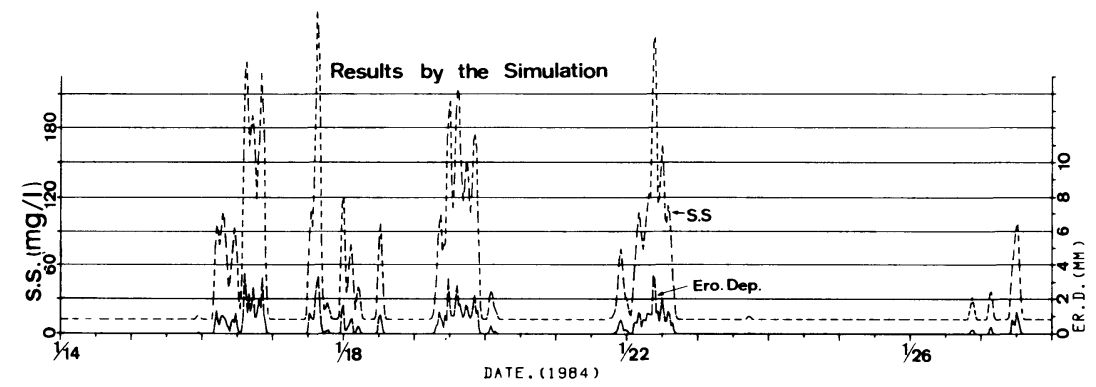

図一8 罣度，風速，風向および浮上厚の時间变化（実測値と計算値の比較）

は再現できた。浮上厚の計算結果は, 風速が $12 \mathrm{~m} / \mathrm{s}$ あ たりで 2〜7 $\mathrm{mm}$ 程度の值となった。これによると, 高 浜入では, 風の強い日には数 $\mathrm{mm}$ 程度の底泥が浮上す る可能性があり，これに伴い底泥間隙水中の栄養塩類が 水圏へ拡散することが予想される.

最後に, 各確率変数の変動係数 $\alpha_{H}, \alpha_{T}$ および $\alpha_{t}$ の值, さらには底泥の限界掃流力 $\tau_{c 2}$ および粘度 $\eta_{1}$ の鉛直分布 が,シミュレーション結果に及ぼす影響について述べる. $\alpha_{H}$ および $\alpha_{T}$ が 0.05 以下であれば，計算結果には大き な変化は現われない. それ以上になると，風速が 10 $\mathrm{m} / \mathrm{s}$ を越すあたりから，計算值は $500 \mathrm{mg} / \mathrm{l}$ をはるかに

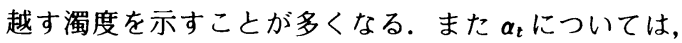
$\alpha_{t}<0.3$ では風速が $6 \mathrm{~m} / \mathrm{s}$ 程度ならば底泥は全く浮上し ない結果となり， $0.5<\alpha_{t}<1$ では $\alpha_{t}$ の増加とともに風 速が $6 \mathrm{~m} / \mathrm{s}$ 程度で濁度の上昇がみられ, 濁度の変動も若 干大きくなる傾向がある. シミュレーション結果に及ぼ す影響は, 底泥の限界掃流力 $\tau_{c 2}$ および粘度 $\eta_{1}$ の鉛直分 布によるものが最も大きかった，底泥が $w=590 \%, \tau_{c 2}$ $=0.21 \mathrm{~N} / \mathrm{m}^{2}, \quad \eta_{1}=0.17 \mathrm{~Pa} \cdot \mathrm{s}$ で鉛直方向に一様とする と, 風速が $7 \mathrm{~m} / \mathrm{s}$ 以下では底泥の浮上は全くなく, 逆に 
$10 \mathrm{~m} / \mathrm{s}$ あたりから濁度は $1000 \mathrm{mg} / \mathrm{l}$ を越し, 浮上厚さ は数 $\mathrm{cm}$ という過大な値となった。 底泥の含水比, 限界 掃流力および粘度の鈶直分布に対する計算結果の感度は $5 \mathrm{~mm}$ 以浅において高く, それ以深では低いので, 表一 1 のような底泥層の分割法が有効であった。

\section{7. 結 論}

霞ケ浦高浜入を対象として，風，湖流，波浪および濁 度の現地観測を行い, 底泥の再浮上に関するシミュレー ションを行った．得られた成果を以下に述べる.

（1）観測結果から，霞ケ浦で起こる底泥の再浮上の 主たる原因は，風により誘起される波浪であることがわ かった.

（2）モデル化にあたり，実効掃流力なる概念を導入 し，波浪による交番性のせん断応力を評価し，鉛直方向 のみの物質収支式で水中での底泥粒子の挙動を記述し た. また，底泥層内の含水比の鉛直変化も考慮した。

（3）濁度についての実測データとシミュレーション 結果の相関係数は 0.67 とかなりよかった.シミュレー ションによれば, $12 \mathrm{~m} / \mathrm{s}$ 程度の風が吹けば, 湖内の濁 度は $200 \sim 300 \mathrm{mg} / l$ 程度に上昇し, 底泥の浮上厚は数 $\mathrm{mm}$ にまでおよぶことになる.

（4） シミュレーション結果は, 波浪や底面せん断応 力の確率変数の特性にも影響されるが, 底泥の限界掃流 力および粘度の鉛直分布，特に $5 \mathrm{~mm}$ 以浅での分布形に 最も影響された。

現地での底泥粒子の粒度分布や比重分布にはある幅が あり,これらの影響を加味したい場合には，各粒度およ び比重別に計算を行って重ね合わせの手法を用いればよ い.また植物プランクトンのように粒径や比重が時間的 に増減する場合には，新たな検討が必要となる．今後十 分に議論されるべき点は，底面での物質収支に関する境 界条件の考え方，すなわち，底泥の浮上と沈殿が同時に 起こっている場合の, 底泥表層での $P_{m}$ (すなわち, $w$, $\left.\eta_{1}, \tau_{c 2}\right)$ や沈殿量 $\left(w_{0} C_{0}\right.$ でよいのか?）の与え方，お よび，底面ごく近傍での拡散係数の与え方などである. また, 最近, 波動場での底泥の挙動に関する研究が盛ん になり，新しい知見が報告されてきている ${ }^{13) \sim 15)}$ ．その 中には, 底泥層の波動運動に伴い, 底泥層内の含水比が
時間とともに高くなることを明らかにし，それが底泥の 飛び出し量に及ぼす影響を評価した例もある ${ }^{15}$. 底泥層 の波動運動が䫓著と思われる現地を対象とする場合に は，このような影響を加味したモデルに改良していく必 要があると思われる.

\section{参文 献}

1) Sheng, Y.P. and Lick, W. : The transport and resuspension of sediments in a shallow lake, J. Geophys. Res., 84 (C4), 1809-1826, 1979.

2）大坪国順・村岡浩爾：底泥の物性および限界掃流力に関 する実験的研究，土木学会論文集，Vol. 363/ II -4, pp. $225 \sim 234,1985$.

3）大坪国順・村岡浩爾：流れによる底泥の飛び出し率，土 木学会論文集, Vol. 375/ II -6, pp. 43 52, 1986.

4）大坪国順・村岡浩爾：霞ケ浦底泥の物性および堆積特性 に関する調査と検討, 土木学会衛生工学研究論文集, Vol. 21, pp. 201 210, 1985.

5）大坪国順・村岡浩爾：霞ケ浦における底泥の再浮上に関 する現地観測及びシミュレーション, 土木学会第 29 回水 理講演会論文集, pp. 353 358, 1985.

6）村岡浩爾・福島武彦：陸水域の富栄養化に関する総合研 究 (四) 霞ヶ浦 (西浦) の湖流, 国立公害研究所研究報告, 第 19 号, 49 60, 1980.

7）たとえば土木学会編：水理公式集 昭和 46 年改訂版, 土 木学会, 480 484, 1971.

8）たとえば土木学会編：新版 土木工学ハンドブック下巻, 技報堂, $2220 \sim 2221,1974$.

9）たとえば，首藤伸夫：新体系土木工学 24 海の波の水理, 技報堂, 1981 .

10）たとえば，石原藤次郎編：水工水理学，丸善，pp. 714〜 $725,1972$.

11）たとえば, 岩佐義朗 : 朝倉土木工学講座 3 水理学, 朝 倉書店, 246 250, 1967 。

12）たとえば，森口繁一・宇田川銈久・一松 信：数学公式 集 III, 岩波書店, 1957 .

13）鶴谷広一・中野 晋・高濱潤：波と底泥の動的相互作 用による底泥の波高减衰と底泥運動, 第 33 回海岸工学講 演会論文集, pp. 317 321，1986.

14）五味美智男 - 矢内栄二 - 堺 和彦 - 大柣 忠 - 系洌長敬 : 波と底泥の相互干渉に及ぼす底泥の影箘について, 第 33 回海岸工学講演会論文集, pp. 322 326, 1986.

15）柴山知也・佐藤慎司：波による底泥の移動現象に関する 研究, 海洋開発論文集, Vol. 3, 1987.

(1987.5.6 • 受付) 